\title{
ANALISA KONSUMSI ENERGI DAN SISTEM PENCAHAYAAN GEDUNG C INSTITUT TEKNOLOGI SUMATERA
}

\author{
Khoirun Naimah ${ }^{1}$, Ahmad Rafi A ${ }^{2}$, Isra D.H1, Philip N \\ Teknik Sistem Energi, Indstitut Teknologi Sumatera, Lampung Selatan, Indonesia ${ }^{1,2,3}$ \\ email: khoirun.naimah@tse.itera.ac.id ${ }^{1}$
}

\begin{abstract}
The role of energy in meeting the basic needs of human life in national development, especially in educational institutions is very important, especially electrical energy. The increase or decrease in activities carried out by educational institutions can have an impact on electricity consumption, such as the Sumatra Institute of Technology campus. Therefore, this study focuses on analyzing and analyzing the profile of the consumption of electrical energy and lighting systems in Building C of the Sumatra Institute of Technology which is used as a lecturer and administration room. The method used is qualitative with field observations and interviews with related parties. The data obtained is then processed so that the IKE value and lighting system information are obtained. The results obtained indicate that (1) Building $C$ is included in the efficient category (2) The lighting system consumes $7 \%$ of the total electricity consumption, and the lighting level of Building $C$ is in accordance with the SNI 6197: 2011 standard (4) Conservation programs that have been carried out namely by using intermittent lights, turning off the lights at 10pm and above and only using the lights on the 1st floor at night, all activities are carried out before $10 \mathrm{pm}$.
\end{abstract}

Keywords: Energy Consumption, Energy Conservation, Lighting System.

\begin{abstract}
Abstrak
Peran energi dalam memenuhi kebutuhan dasar kehidupan manusia dalam pembangunan nasional khususnya dalam lembaga pendidikan sangat penting, khususnya energi listrik. Peningkatan maupun penurunan kegiatan yang dilakukan oleh lembaga pendidikan dapat memberikan dampak pada konsumsi energi listrik, seperti kampus Institut Teknologi Sumatera. Oleh karena itu, penelitian ini berfokus untuk mengetahui dan menganalisis profil konsumsi energi listrik dan sistem pencahayaan di Gedung $\mathrm{C}$ Institut Teknologi Sumatera yang digunakan sebagai ruang dosen dan administrasi. Metode yang digunakan adalah secara kualitatif dengan observasi lapangan dan wawancara dengan pihak terkait. Data yang diperoleh kemudian diolah sehinggan diperoleh nilai IKE dan informasi sistem pencahayaan. Hasil yang diperoleh menunjukkan bahwa (1) Gedung C termasuk dalam kategori efisien (2) Sistem pencahayaan mengkonsumsi energi listrik 7\% dari total konsumsi listrik, dan tingkat pencahayaan Gedung C sudah sesuai dengan standard SNI 6197:2011 (4) Program konservasi yang sudah dilakukan yaitu dengan menyalakan lampu selang seling, mematikan lampu saat jam 10 malam keatas dan hanya menggunakan lampu pada lantai 1 ketika malam hari, semua kegiatan pembersihan dilakukan sebelum jam 10 malam.
\end{abstract}

Kata Kunci: Konsumsi Energi, Konservasi Energi, Sistem Pencahayaan.

\section{PENDAHULUAN}

Peran energi dalam memenuhi kebutuhan dasar kehidupan manusia khususnya dalam pembangunan ekonomi nasional berkelanjutan sangatlah penting. Peningkatan kebutuhan energi berbanding lurus dengan peningkatan pertumbuhan ekonomi dan pertumbuhan penduduk. Energi fosil seperti minyak bumi, gas bumi, dan batubara merupakan salah satu sumber energi tak terbarukan, memerlukan waktu ribuan tahun untuk mampu memproduksinya, dan jumlahnya terbatas, sehingga akan habis dalam kurun waktu tertentu. Selain jumlahnya yang terbatas, dalam proses produksi/konversinya, energi fossil cenderung memberikan dampak negatif terhadap lingkungan seperti emisi GRK yang lebih besar dibandingkan energi terbarukan. Namun, penggunaan energi terbarukan tersebut secara kuantitas/volume masih lebih kecil dibandingkan energi fosil, sehingga energi fosil masih akan terus mendominasi hingga tahun 2050 [1]. Sehingga dibutuhkan berbagai upaya untuk mencari sumber energi lain atau menggunakan sumber energi terbarukan dan yang terpenting adalah efisiensi energi guna melestarikan sumber daya energi [2].

Oleh karena itu, untuk mendukung program pemerintah tentang konservasi energi dan efisiensi energi khususnya pada bangunan gedung maka diperlukan analisis hasil nilai Intensitas Konsumsi Energi (IKE) untuk mengetahui penggunaan/konsumsi energi dari peralatan elektronik yang digunakan per luas bangunan gedung tersebut. Hal ini karena penggunaan energi listrik dalam suatu bangunan erat kaitannya dengan teknologi/peralatan yang digunakan didalamnya guna memperlancar suatu kegiatan. Teknologi/peralatan yang paling banyak ada didalam suatu gedung adalah pada sistem pencahayaan dan pendinginan/pengudaraan. Selain itu juga terdapat peralatan penunjang lain seperti komputer, printer, dan sebagainya yang disesuaikan dengan fungsi gedung di masing-masing tempat. Standar yang dijadikan acuan untuk menilai IKE pada suatu bangunan adalah berdasarkan Kriteria IKE dari Departemen Pendidikan Nasional Republik Indonesia, 2004 dan Sistem Pencahayaan berdasarkan Standar Nasional Indonesia (SNI) 6197:2011.

Bangunan gedung yang dipilih dalam penelitian ini adalah bangunan gedung pendidikan dengan fokus pada Gedung C Institut Teknologi Sumatera (ITERA), Lampung Selatan, Provinsi Lampung, Indonesia. ITERA merupakan Lembaga Institusi Pendidikan yang resmi didirikan pada tahun 2014. Sebagai institusi pendidikan baru, pembangunan sarana dan prasarana penting guna menunjang keberlancaran dan kenyamanan dalam beraktivitas. Sehingga, hal tersebut tentu harus dipersiapkan dengan matang terutama terkait energi listrik. Gedung ini difungsikan sebagai tempat perkuliahan untuk mahasiswa dan digunakan untuk ruangan 
tendik atau dosen. Sehingga, gedung ini terdiri dari 3 lantai dan memuat ribuan mahasiswa. Gedung ini beroperasi pada hari kerja senin-jumat dari pukul 07.00-18.00. Adapun jam operasional tambahan diberlakukan berdasarkan kebutuhan tertentu. Oleh karena itu, penelitian ini berfokus untuk mengetahui dan menganalisis profil penggunaan energi/konsumsi energi listrik pada gedung $\mathrm{C}$ dan program konservasi energi yang sudah dan/atau harus dilakukan khususnya pada sistem pencahayaan gedung C ITERA.

\section{KAJIAN PUSTAKA}

\section{A. Konservasi Energi}

Regulasi dari program Konservasi Energi telah ditetapkan pada Peraturan Pemerintah No. 70 Tahun 2009 tentang Konservasi Energi yang merupakan suatu upaya sistematis, terencana, dan terpadu guna melestarikan sumber daya energi dalam negeri serta meningkatkan efisiensi pemanfaatannya. Sehingga, konservasi energi lebih mengarah pada upaya yang dilakukan oleh manusia untuk meningkatkan efisiensi dalam pemanfaatan energi pada suatu sistem dengan tetap menggunakan energi secara rasional tapi tetap mempertahankan produktifitas.

Peluang konservasi energi menurut Standar Nasional Indonesia (SNI) 6196:2011 diartikan sebagai peluang yang mungkin bisa diperoleh dalam rangka penghematan energi dengan cara perbaikan dalam pengoperasian dan pemeliharaan, atau melakukan tindakan konservasi energi pada fasilitas energi. Peluang konservasi energi merupakan langkah lanjutan dalam penghematan energi yang mengatur kinerja enmulai dari pengadaan, pemeliharaan operasional, sampai pada titik penggantian energi ulang.

\section{B. Intensitas Konsumsi Energi (IKE)}

Teknik yang dipakai untuk menghitung besarnya konsumsi energi pada bangunan gedung dan mengenali cara-cara untuk penghematannya. Intensitas Konsumsi Energi (IKE) Listrik adalah pembagian antara konsumsi energi listrik pada kurun waktu tertentu dengan satuan luas bangunan gedung. Indikator utama penghematan energi di sebuah gedung umumnya menggunakan Intensitas Konsumsi Energi (IKE). IKE menunjukkan besarnya konsumsi energi (kwh) per meter persegi $\left(\mathrm{m}^{2}\right)$ setiap bulan. Angka IKE $\left(\mathrm{kwh} / \mathrm{m}^{2} /\right.$ bulan) diperoleh dengan membagi jumlah kwh penggunaan listrik selama sebulan dengan luas bangunan yang digunakan. Perhitungan nilai IKE bangunan Gedung disesuaikan dengan jenis gedung tersebut apakah tergolong kedalam bangunan gedung ber-AC, tanpa $\mathrm{AC}$, atau ber-AC dan tanpa AC [3]. Sehingga perhitungan IKE/Konsumsi Energi Spesifik gedung tersebut dapat terlihat pada pers (1) dan (2).

$$
\begin{aligned}
& \text { a. Lantai ber-AC } \\
& I K E=\frac{a}{b} x \frac{c-a}{d}
\end{aligned}
$$

Ket.

$\mathrm{a}=$ Konsumsi energi dari AC (kWh)

$\mathrm{b}=$ Luas Ruangan ber AC $\left(\mathrm{m}^{2}\right)$

$\mathrm{c}=$ Total Konsumsi energi listrik $(\mathrm{kWh})$

$\mathrm{d}=$ Total Luas Ruangan $\left(\mathrm{m}^{2}\right)$

b. Lantai tanpa-AC

$I K E=\frac{\text { Total Konsumsi Listrik }(K w h)}{\text { Luas Total Ruangan tanpa } A C\left(m^{2}\right)}$
Menurut Pedoman Pelaksanaan Konservasi Energi dan Pengawasannya di Lingkungan Departemen Pendidikan Nasional nilai IKE dari suatu bangunan gedung digolongkan dalam dua kriteria, yaitu untuk bangunan berAC dan bangunan tidak ber- AC. Tabel 1. menunjukkan kriteria IKE bangunan berdasarkan Kriteria IKE Departemen Pendidikan Nasional Republik Indonesia, 2004.

Tbl 1 IKE standar pada bangunan AC dan non-AC [4]

\begin{tabular}{|c|c|c|}
\hline Kriteria & $\begin{array}{c}\text { Ruangan AC } \\
\left(\mathrm{kWh} / \mathrm{m}^{2} / \mathrm{bulan}\right)\end{array}$ & $\begin{array}{c}\text { Ruangan non AC } \\
\left(\mathrm{kWh} / \mathrm{m}^{2} / \mathrm{bulan}\right)\end{array}$ \\
\hline Sangat Efisien & $4,17-7,92$ & $0,84-1,67$ \\
\hline Efisien & $7,92-12,08$ & $1,67-2,5$ \\
\hline Cukup Efisien & $12,08-14,48$ & - \\
\hline Agak Boros & $14,48-19,17$ & - \\
\hline Boros & $19,17-23,75$ & $2,5-3,34$ \\
\hline Sangat Boros & $23,75-37,75$ & $3,34-4,17$ \\
\hline
\end{tabular}

\section{Sistem Pencahayaan}

Sistem pencahayaan pada suatu bangunan terdiri atas sistem pencahayaan alami dan buatan. Pencahayaan alami adalah pencahayaan yang berasal dari cahaya matahari dan harus dapat dimanfaatkan sebaik-baiknya untuk mengurangi energi listrik pada bangunan [5]. Pencahayaan alami memiliki dampak terhadap meningkatnya suhu ruangan dikarenakan radiasi matahari. Pencahayaan buatan merupakan pencahayaan yang dihasilkan oleh sumber cahaya buatan manusia. Pencahayaan buatan diperlukan apabila posisi ruangan sulit dicapai oleh pencahayaan alami. Kualitas pencahayaan pada suatu permukaan atau bidang kerja dinyatakan dengan satuan lux. Tingkat pencahayaan minimum yang direkomendasikan pada lembaga pendidikan ditunjukkan pada tabel 2.

Tbl 2 Tingkat pencahayaan minimum pada lembaga pendidikan [6]

\begin{tabular}{|c|c|}
\hline Fungsi Ruangan & $\begin{array}{c}\text { Tingkat } \\
\text { Pencahayaan (lux) }\end{array}$ \\
\hline Ruang Kelas & 350 \\
\hline Laboratorium & 500 \\
\hline Ruang praktek komputer & 500 \\
\hline Ruang laboratorium bahasa & 300 \\
\hline Ruang guru & 300 \\
\hline Lobby & 350 \\
\hline
\end{tabular}

Standar ini memuat ketentuan pedoman pencahayaan pada bangunan gedung untuk memperoleh sistem pencahayaan dengan pengoperasian yang optimal sehingga penggunaan energi lebih efisien tanpa harus mengurangi dan atau mengubah fungsi bangunan, kenyamanan dan produktivitas penghuni, serta mempertimbangkan aspek ramah lingkungan.

Selain tingkat pencahayaan, renderasi warna juga perlu untuk diketahui. Renderasi warna atau color rendering index (CRI) merupakan efek psikofisik suatu sumber cahaya atau lampu terhadap warna objek yang diterangi (SNI 03-6575-2001). CRI dinyatakan dalam suatu angka indeks yang diperoleh berdsarkan perbandingan dengan efek warna sumber cahaya referensi pada kondisi yang sama. Nilai maksimum teoritis dari indeks renderasi warna 
dalah 100 dan dinyatakan dengan Ra. Ada empat kelompok renderasi warna yang dapat dipakai. Tabel 3 memperlihatkan pengelompokkan CRI [7].

Tbl 3 Pengelompokkan renderasi warna

\begin{tabular}{|c|c|c|}
\hline Kel. & Indeks & Aplikasi \\
\hline 1A & $\mathrm{Ra}>90$ & $\begin{array}{c}\text { Saat CRI yang akurat sangat } \\
\text { diperlukan, seperti inspeksi } \\
\text { pencetakkan warna }\end{array}$ \\
\hline 1B & $80>\mathrm{Ra}>90$ & $\begin{array}{c}\text { Saat CRI yang baik } \\
\text { dipertimbangkan untuk } \\
\text { keperluan tampilan, seperti } \\
\text { display lighting }\end{array}$ \\
\hline 2 & $60>\mathrm{Ra}>80$ & $\begin{array}{c}\text { Saat rendering warna yang } \\
\text { sedang diperlukan }\end{array}$ \\
\hline 3 & $40>\mathrm{Ra}>60$ & $\begin{array}{c}\text { kapan pun rendering warna tidak } \\
\text { terlalu penting tetapi distorsi warna } \\
\text { yang ditandai tidak dapat diterima }\end{array}$ \\
\hline 4 & $20>\mathrm{Ra}>40$ & $\begin{array}{c}\text { kapan pun rendering warna tidak } \\
\text { penting sama sekali dan distorsi } \\
\text { warna yang ditandai dapat diterima }\end{array}$ \\
\hline
\end{tabular}

\section{METODE}

Metode yang digunakan dalam penelitian ini adalah secara kualitatif dengan observasi secara langsung di lapangan dan wawancara dengan pihak terkait. Obyek dalam penelitian ini adalah konsumsi energi listrik dan program/upaya konservasi energi pada sistem pencahayaan pada bangunan gedung $C$ bulan Desember 2020. Flowchart penelitian ini terlihat pada Gambar 1.

Dari Gambar 1. Dapat dilihat bahwa Penelitian dimulai dengan start dengan kegiatan studi literature, lalu dilanjutkan dengan pengumpulan data bangunan melalui observasi langsung di lapangan berupa luas bangunan, orientasi bangunan, daya alat elektronik, dan intensitas cahaya (lux). Kemudian, dilanjutkan dengan wawancara dengan pihak terkait agar dapat dihasilkan data konsumsi energi listrik. Data dikumpulkan secara kolektif tiap lantai pada gedung C ITERA. Instrumen atau alat yang digunakan untuk mengumpulkan data diantaranya adalah kompas, meteran, luxmeter, dan Microsoft excel. Data yang dikumpulkan kemudian diolah dan dianalisis sehingga diperoleh kesimpulan dan selesai.

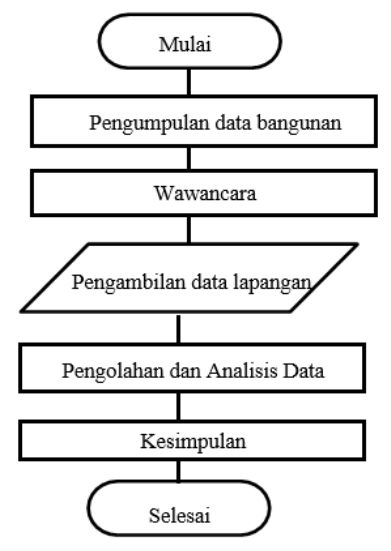

Gbr 1 Diagram Alir Penelitian

\section{HASIL DAN PEMBAHASAN}

A. Hasil

1) Data Bangunan Gedung

Tbl 4 Fungsi dan orientasi bangunan gedung $\mathrm{C}$

\begin{tabular}{|c|c|c|}
\hline $\begin{array}{c}\text { Nama } \\
\text { Gedung }\end{array}$ & Fungsi Gedung & Orientasi \\
\hline Gedung C & $\begin{array}{c}\text { Ruang kelas, dosen dan } \\
\text { administrasi }\end{array}$ & Utara \\
\hline
\end{tabular}

Tbl 5 Luas bangunan gedung C

\begin{tabular}{|c|c|c|c|c|}
\hline \multirow{2}{*}{ No. } & \multirow{2}{*}{ Lantai } & \multicolumn{2}{|c|}{ Ruangan } & Total \\
\cline { 3 - 4 } & & $\mathrm{AC}\left(\mathrm{m}^{2}\right)$ & Non $\mathrm{AC}\left(\mathrm{m}^{2}\right)$ & $\left(\mathrm{m}^{2}\right)$ \\
\hline 1 & 1 & 665 & 423 & 1088 \\
\hline 2 & 2 & 354.4 & 698.6 & 1053 \\
\hline 3 & 3 & 851.2 & 180 & 1031.2 \\
\hline \multicolumn{2}{|c|}{ Total } & 1870.6 & 1301.6 & 3172.2 \\
\hline
\end{tabular}

2) Data Pemakaian Energi Listrik Gedung C

Tbl 6 Pemakaian energi listrik bangunan gedung C

\begin{tabular}{|c|c|c|c|}
\hline No. & Lantai & $\begin{array}{c}\text { Total Konsumsi } \\
\text { Energi Listrik } \\
(\text { Kwh/bulan })\end{array}$ & $\begin{array}{c}\text { Konsumsi Energi } \\
\text { Listrik dari AC } \\
(\text { Kwh/bulan })\end{array}$ \\
\hline 1 & 1 & 7452.4 & 6229.8 \\
\hline 2 & 2 & 3955.6 & 3454.2 \\
\hline 3 & 3 & 335.1 & - \\
\hline \multicolumn{2}{|c|}{ Total } & 11743.1 & 9684 \\
\hline
\end{tabular}

3) Data Sistem Pencahayaan Aktif Gedung C

Tbl 7 Lighting level of C Building

\begin{tabular}{|c|c|c|c|c|}
\hline \multirow{2}{*}{ Lantai } & Fungsi & Luas $\left(\mathrm{m}^{2}\right)$ & $\begin{array}{c}\text { Lighting } \\
\text { Level } \\
(\text { Lux })\end{array}$ & CRI \\
\hline \multirow{2}{*}{1} & Dosen C104 & 112.5 & 260 & 85 \\
\cline { 2 - 5 } & Dosen C110 & 151.8 & 260 & 85 \\
\hline \multirow{2}{*}{2} & Dosen C204 & 112.5 & 260 & 85 \\
\cline { 2 - 5 } & Dosen C210 & 151.8 & 260 & 85 \\
\hline
\end{tabular}

\section{B. Pembahasan}

1) Karakteristik Bangunan Gedung

Secara orientasi, bangunan gedung C sebagaimana terdapat pada Table 3. yaitu menghadap utara yangmana orientasi ini memiliki faktor radiasi matahari yang cukup besar sehingga dapat dengan mudah memperoleh sinar matahari secara langsung. Fungsi bangunan gedung $\mathrm{C}$ sebagai tempat perkuliahan, ruang dosen, dan administrasi. Secara rinci dari fungsi ruangan. yaitu sebagian besar adalah ruang dosen, ruang kelas, dan ruang lab. Namun, untuk kondisi saat ini hanya ruang dosen yang sering digunakan karena perkuliahan dilakukan secara daring. Adapun tampak depan dan belakang dari bangunan gedung $\mathrm{C}$ dapat dilihat pada Gambar 2. 


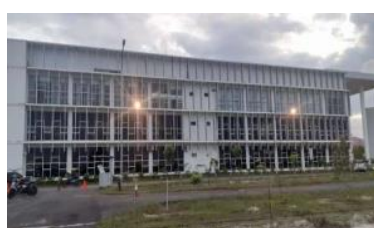

(a)

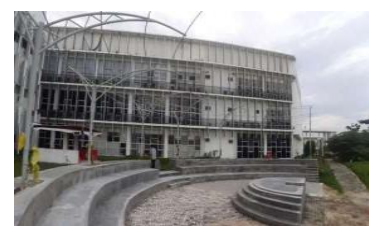

(b)
Gbr 2 (a) Tampak depan (b) tampak belakang Gedung C

Total luas bangunan gedung $\mathrm{C}$ sebagaimana terdapat dalam Table 4. adalah $3172.2 \mathrm{~m}^{2}$ dengan ruangan AC memiliki luas $1870.6 \mathrm{~m}^{2}$ dan Non-AC $1301.6 \mathrm{~m}^{2}$, sehingga dapat dikategorikan bahwa gedung $\mathrm{C}$ termasuk dalam kategori gedung ber-AC. Data ini digunakan untuk membandingkan dengan standar yang akan digunakan untuk menilai Intensitas Konsumsi Energi.

\section{2) Pemakaian Energi Listrik Gedung C}

Pemakaian energi listrik/konsumsi energi listrik digunakan untuk melihat profil pemakaian/konsumsi energi listrik dan penilaian Intensitas Konsumsi Energi gedung C. Dari data pada Table 5. Dapat dilihat bahwa konsumsi energi listrik gedung $\mathrm{C}$ adalah 11743.1 $\mathrm{Kwh} /$ bulan, dengan porsi paling besar adalah lantai 1 yaitu $7452.4 \mathrm{Kwh} /$ bulan. Hal ini karena selama bulan Desember dengan 20 hari kerja, lantai 1 merupakan lantai dengan ruangan yang paling sering digunakan untuk beraktivitas dengan 9 ruang aktif yaitu 3 ruang dosen, 1 ruang adm, 1 ruang pengadaan, 1 ruang panel, dan 3 toilet. Sedangkan dilantai 2 hanya 5 ruang aktif yaitu 2 ruang dosen, 2 toilet, dan 1 ruang panel. Sementara di lantai 3 penggunaan energi listrik sangat kecil dibanding lantai 1 maupun 2, karena tidak ada kegiatan akibat pandemi, Sementara itu, pompa hanya di gunakan ketika tanki penyimpanan air mendekati habis.

Untuk mengetahui performa bangunan gedung boros atau efisien maka dilakukan perhitungan nilai Intensitas Konsumsi Energi (IKE) sesuai dengan criteria bangunan tersebut. Pada penelitian ini, pada lantai 1 dan 2 merupakan lantai yang masih sering digunakan untuk aktivitas kerja, sedangkan lantai 3 tidak pernah digunakan selama kondisi pandemic, sehingga AC yang terdapat pada ruangan-ruangan di lantai 3 tersebut juga tidak digunakan. Perhitungan nilai IKE bangunan Gedung disesuaikan dengan jenis gedung tersebut apakah tergolong kedalam bangunan gedung ber-AC, tanpa AC, atau ber-AC dan tanpa AC. Dalam penelitian ini, Gedung $\mathrm{C}$ tergolong kedalam bangunan gedung ber-AC dan tanpa AC. Hasil perhitungan nilai IKE tersebut dapat terlihat pada Tabel 8.

Tbl 8 Nilai IKE Gedung C

\begin{tabular}{|c|c|c|}
\hline No & Lantai & $\begin{array}{l}\text { Intensitas Konsumsi Energi } \\
\left.\text { Listrik (Kwh/bulan/m }{ }^{2}\right)\end{array}$ \\
\hline 1 & 1 & 10.49 \\
\hline 2 & 2 & 4.64 \\
\hline 3 & 3 & 2.57 \\
\hline
\end{tabular}

Dari Tabel 8. maka dapat dilihat bahwa lantai 1 memiliki nilai IKE yang lebih besar dibanding lantai 2 dan 3. Sesuai dengan standar dari Departemen Pendidikan Nasional Republik Indonesia, 2004 maka kategori pengunaan listrik untuk gedung $\mathrm{C}$ lantai 1 adalah efisien, kemudian untuk lantai 2 dan 3 adalah sangat efisien. Hal ini dikarenakana banyak AC, lampu, dan beberapa peralatan elektronik seperti lift yang tidak dipakai karena tidak ada kegiatan atau aktivitas di gedung $\mathrm{C}$ akibat pandemi. Profil penggunaan energi listrik di Gedung $\mathrm{C}$ dapat erlihat pada Gambar 3. Dari Gambar 3. terlihat bahwa sebagian besar atau 78,78\% konsumsi energi listrik adalah dari sistem AC.

Presentase Konsumsi Listrik (\%)

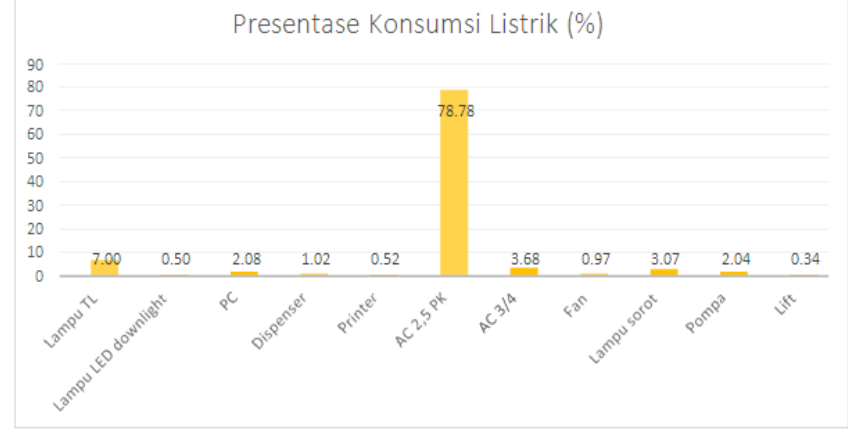

Gbr 3 Profil konsumsi energi listrik di gedung C

Dari Gambar 3. dapat dianalisis bahwa pengunaan energi listrik pada gedung $\mathrm{C}$ terbesar adalah AC 2.5 PK, yang kemudian disusul oleh lampu TL. Lampu TL digunakan pada tiap tiap ruangan, dan lobby. Sementara itu, lampu LED downlight hanya digunakan di toilet. Pengunaan PC/laptop dihitung hanya ketika Laptop tersebut di charge, Dispenser yang ada pada tiap tiap ruang dosen diasumsikan hanya digunakan selama 3 jam perhari yang di gunakan hanya ketika ingin memanaskan air. Printer hanya di nyalakan ketika hanya ingin mencetak dokumen. Fan/exhaust dihubungkan seri dengan sakelar lampu, jika lampu toilet dinyalakan, maka fan tersebut juga menyala. Gedung C memiliki 3 lampu sorot yang posisinya dua lampu dipasang di depan gedung menghadap ke parkiran motor gedung $\mathrm{C}$, satunya lagi dipasang menghadap gladiator/embung $\mathrm{C}$. Gedung $\mathrm{C}$ juga memiliki satu unit pompa untuk mensuplai air di gedung $\mathrm{C}$ dan Gedung $\mathrm{D}$ dan satu lift yang pengoperasiannya jarang di gunakan.

\section{3) Sistem Pencahayaan Gedung $C$}

Beban pencahayaan buatan yang digunakan pada bangunan gedung $\mathrm{C}$ rata- rata adalah jenis lampu TL 18 watt dan LED downlight bulb 9 watt. Jenis lampu tersebut merupakan jenis lampu yang efisien dan memiliki umur yang > 35.000 jam dibanding jenis lainnya, sehingga sudah tepat pihak ITERA dalam memilih jenis lampu yang digunakan untuk bangunan gedung tersebut. Namun, lampu LED lebih ramah lingkungan dibanding jenis TL karena tidak mengandung merkuri sedangkan lampu TL masih mengandung sedikit merkuri. Pengukuran intensitas pencahayaan dilakukan langsung di dibawah objek penelitian (lampu) dengan menggunakan titik pengukuran penerangan umum (pengukuran seluruh area ruangan) setara tinggi meja kantor [8]. 
Total beban pencahayaan terpasang di gedung C adalah 822,4 kW. Sehingga didapatkan persentase pemakaian energi listrik untuk sistem pencahayaan adalah 7\%. Dari Table 6. juga dapat dilihat bahwa untuk ruangan dosen yang berada di lantai 1 maupun lantai 2 dari segi tingkat pencahayaan berada dibawah batas standar SNI 6197:2011 yang direkomendasikan, sedangkan daya maksimum sudah berada dibawah dari daya maksimum yang diizinkan oleh SNI 6197:2011. Hal ini karena orientasi bangunan tersebut memiliki sisi kemudahan masuknya sinar matahari kedalam ruangan. Namun, tetap diperlukan upaya konservasi energi agar tingkat kenyamanan dalam aktivitas tetap terjaga dan energi listrik dapat digunakan dengan bijak.

Perbandingan hasil pengukuran saat ini dan SNI 6197:2011 dari tingkat pencahayaan dan daya maksimum pada lembaga pendidikan ruang guru terlihat pada Tabel 9.

Tbl 9 Perbandingan hasil saat ini dengan SNI 6197:2011

\begin{tabular}{|c|c|c|c|c|c|}
\hline \multirow[t]{2}{*}{ Lantai } & \multirow{2}{*}{$\begin{array}{l}\text { Fungsi } \\
\text { ruangan }\end{array}$} & \multicolumn{2}{|c|}{$\begin{array}{c}\text { Tingkat } \\
\text { Pencahayaan (Lux) }\end{array}$} & \multicolumn{2}{|c|}{$\begin{array}{l}\text { Daya Maks } \\
\left(\mathrm{W} / \mathrm{m}^{2}\right)\end{array}$} \\
\hline & & Hasil & SNI & Hasil & SNI \\
\hline \multirow{2}{*}{1} & $\begin{array}{l}\text { Dosen } \\
\text { C104 }\end{array}$ & 260 & 300 & 1.92 & 12 \\
\hline & $\begin{array}{l}\text { Dosen } \\
\text { C110 }\end{array}$ & 260 & 300 & 2.13 & 12 \\
\hline \multirow{2}{*}{2} & $\begin{array}{l}\text { Dosen } \\
\text { C204 }\end{array}$ & 260 & 300 & 1.92 & 12 \\
\hline & $\begin{array}{l}\text { Dosen } \\
\text { C210 }\end{array}$ & 260 & 300 & 2.13 & 12 \\
\hline
\end{tabular}

Selain itu, ada beberapa kegiatan konservasi yang telah dilakukan oleh pihak gedung secara sadar atau tidak sadar, yaitu dengan menyalakan lampu selang seling seperti Gambar 4, mematikan lampu saat jam 10 malam keatas dan hanya menggunakan lampu pada lantai 1 ketika malam hari, semua kegiatan pembersihan dilakukan sebelum jam 10 malam. Di himbau pada malam hari, jangan meninggalkan ruangan sementara lampu menyala dan alat elektronik lainnya tidak dalam keadaan mati karena meningkatkan pemborosan listrik.

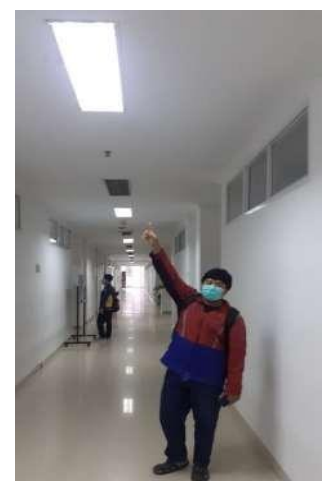

Gbr 4 Salah satu program konservasi energi

\section{KESIMPULAN}

Dari penelitian yang telah dilakukan maka dapat disimpulkan bahwa performa energi pada bangunan gedung C ITERA memiliki nilai IKE yang sangat efisien dengan nilai $3,70 \mathrm{kWh} / \mathrm{m} 2$ /bulan. Penggunaan energi didominasi oleh sistem AC sebesar 78.78\%, dan dari sistem pencahayaan berada dibawah Standar SNI 6197:2011 tetapi masih bisa dicari peluang untuk konservasi energi yaitu mengganti lampu TL ballast Konvensional dengan ballast elektronik dan tetap mempertahankan upaya konservasi yang telah diterapkan sehingga, bangunan gedung $\mathrm{C}$ dapat lebih efisien.

\section{REFERENSI}

[1] BPPT, Outlook Energi Indonesia. Jakarta:BPPT, 2020

[2] Peraturan Pemerintah No. 70 Tahun 2009 tentang Konservasi Energi

[3] USAID Indonesia Clean Energy Development (ICED Project), Panduan Penghematan Energi di Gedung Pemerintahan. Jakarta:USAID Indonesia, 2014

[4] Badan Standardisasi Nasional. SNI 03- 6196-2000, Prosedur Audit Energi Pada Bangunan Gedung. Jakarta: BSN. (ID): Departemen Pendidikan Nasional, 2004.

[5] Illahi, S. N., Priatna, E., \& Hiron, N. (2020). Analisis Konservasi Energi Pada Sistem Pencahayaan Dan Sistem Pendingin Di Kantor Sekretaris Daerah Kabupaten Garut. Journal of Energy and Electrical Engineering, 1(2).

[6] Badan Standarisasi Nasional. SNI 6197:2011 Konservasi Energi Pada Sistem Pencahayaan. Jakarta: BSN, 2011.

[7] Ministry of Power India. Best Practice Manual Lighting. India: Bureau of Energy Efficiency, 2005.

[8] Badan Standarisasi Nasional. SNI 7062:2019 Pengukuran Intensitas Pencahayaan ditempat kerja. Jakarta: BSN, 2019.

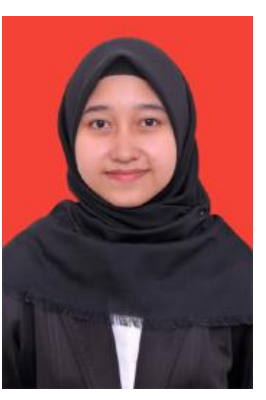

\section{BIOGRAFI PENULIS}

Khoirun Naimah, Lahir di Sumber Agung, 7 Juni 1996. Riwayat Pendidikan D4 Teknik Energi Politeknik Negeri Sriwijaya dan S2 Ketahanan Energi Universitas Pertahanan Indonesia. Saat ini bekerja sebagai Dosen Teknik Sistem Energi Institut Teknologi Sumatera, dengan fokus penelitian pada kelompok keilmuan manajemen dan audit energi (konservasi energi). Paper ini ditulis bersama dengan Mahasiswa Teknik Sistem Energi Institut Teknologi Sumatera. 